\title{
Biochemical study of hepatoprotective collection of plant origin
}

\author{
(C) Anatoly A. Lapin, ${ }^{1}{ }^{+}$Irek G. Garifullin, ${ }^{2}$ and Valery N. Zelenkov ${ }^{3}$ \\ ${ }^{1}$ Kazan State Power Engineering University. Krasnoselskaya St., 51. Kazan, 420066. Republic of Tatarstan. \\ Russian Federation.Phone: +7 (843) 519-42-67.E-mail: lapinanatol@mail.ru \\ ${ }^{2}$ NLLC "Clinic of green medicine". Galimzhan Barudi St., 4, room 2039. Kazan, 420032. \\ Republic of Tatarstan.Russia.Phone: +7 (917)284-47-77.E-mail: ireknl@mail.ru \\ ${ }^{3}$ All-Russian Research Institute of Medicinal and Aromatic Plants. Green St., 7. Moscow, 117216. \\ E-mail: zelenkov-raen@mail.ru
}

\begin{abstract}
*Supervising author; ${ }^{+}$Corresponding author
Keywords: antioxidant activity, total antioxidant activity, coulometric analysis method, hepatoprotectors of plant origin.
\end{abstract}

\section{Abstract}

The article presents the results of biochemical studies of the total antioxidant activity of the hepatoprotective collection of plant origin and its individual components, which show that it consists of birch leaves (Betulae folia), tansy flowers (Tanaceti flores), phytohepatol No. 2 (choleretic collection No. 2) and individual its components have pronounced antioxidant activity. More antioxidant activity founded in tansy and true hepatoprotective collection. Comparative tests of the flowers of meadowsweet, with the highest antioxidant activity, showed the promise of their use in the collections of medicinal plants as effective natural metabolic regulators. The total antioxidant activity of the water extract collection at $13.56 \%$ rel. exceeded the calculated value obtained by summing the activities of the individual components of the collection, which indicates the presence of synergism in their action, which may be of value for use in the treatment and prevention of liver diseases. When all components of the drug collection are finished, the indicator increases by 11-24\% rel., which indicates the thermal stability of the antioxidant substances that make up their composition. In the oxidation of aqueous extracts of the components of hepatoprotective collection with hydrogen peroxide, the most stable were antioxidants of birch leaves. It was found that collection only at a ratio of $7.7 \mathrm{~g}$ per liter of water shows synergism (15\% rel.), and the rest of all the samples we tested are antagonistic. The detected increase in the antioxidant activity of the new collection compared with the effects of its individual components allows us to consider it as a promising dosage form for use in the treatment and prevention of liver diseases.

\section{References}

[1] Y.G. Bazarnova. De studiis antioxidant proprietatibus quibusdam excerptis ex plantis phenolic suis Revolutionibus componit. Phil. Ac. Acta Internationalis, Technical Conference "Resource-saving in cibum productio technology." St.Petersburgb: Publishing Domus SPbGAHTP. 1998. P.193. (russian)

[2] G. Bartosz. Total antioxidant capacity. Adv Clin Chem. 2003. Vol.37. P.219-292.

[3] V.F. Gromovaya, G.S. Shapoval, I.E. Myronyuk. Antioxidant proprietates medicinales plantis. Res, Pharm. La. 2008. Vol.42. No.1. P.26-29. (russian)

[4] A.A. Lapin, M.A. Demidova, V.V. Meltonyan, V.N. Zelenkov. Actus a medicis herbarum oxidant aestimatio aqueum excerpta. Natural resources, innovation technologies and products: Collected scientific works. Iss.20. Moscow: Izd RANS. 2012. P.21-26. (russian)

[5] I.E. Kauhova. Procedure Novum licet ad paranda medicamenta herbal. Pills. 2006. No.1. P.37-39. (russian)

[6] Ye.A. Ushkalova. Problems of application a iocineris. Farmateka. 2004. No.4. P.45-55. (russian)

[7] V.N. Zelenkov, A.A. Lapin. MVI-001-44538054-07. Antioxidant totalem actionem. In mensura modi coulometric analyzer. VNII a Prunus cerasus. Vereya, regionis Moscow. 2013. 19p. (russian)

[8] TU 9369-141-04868244-07. Rutin - a vexillum cf. Technical conditionibus.

[9] In re publica Pharmacopoeia in USSR. Iss.2. General analysis de modi. Herbal medicamenta. Insecta Ministerio Salutem. XI ed., ext. Moscow: Medicinae. 1989. 398p. (Reference date 04.25.2019).

[10] D. Yezepov. Fashion in mutant. [Electronic resource] - URL: http:// statanaliz.info/metody/opisaniedannyx/56-moda (Reference date 04.25.2019). 
[11] V.E. Novikov, E.I. Klimkina. Materia Medica gepatoprotektorov. Ipsa rei recensionem. Farmacol wedge. Lek. ter. 2005. Vol.4. No.1. P.2-20. (russian)

[12] O.U. Katikova, Y.V. Kostin, V.S. Tishkin. Hepatoprotective effectus medicinae ex herba originem. Experimentum. Farmacol wedge. 2002. Vol.65. No.1. P.41-43. (russian)

[13] N.N. Karkischenko. Environmental pharmacologicae et orci in verbis formas et notiones valde. $1 M P$ Medicina. 1995. 304p. (russian)

[14] O.N. Minushkin. Some hepatoprotectors in the treatment of liver disease. Therapist. 2002. No.6. S.5558. (russian)

[15] L.T. Kozaeva, A.A. Lapin, V.N. Zelenkov. Infusa aqua, studio atque aquosus deprehenditur-alcoholico deliberemus Filipendula Ulmaria. Natural resources, innovation technologies and products: Collected scientific works. Iss.15. Moscow: Izd RANS. 2007. P.72-76. (russian)

[16] T.M. Pashkov. Effectus autem infusa herbe antioxidant medicinalis operatio, et operatione antilysozyme KLEBSIELLA PNEUMONIAE. De rebus faustis scientiae. 2007. No.7. P.60-60. (russian)

[17] E.V. Ferubko, V.N. Zelenkov, A.A. Lapin, T.D. Dargaeva. Antigepatoksicheskogo colligendis actio et operatio a studiis antioxidant fuerit per components. Plantae novae et ligula ac fortunis sui usus: $C$. XIII International Symposium materiae. Moscow: RUDN. 2019. 184p. P.179-181. (russian)

[18] E.V. Ferubko, V.N. Zelenkov, A.A. Lapin, T.D. Dargaeva. Antigepatoksicheskogo colligendis actio et operatio a studiis antioxidant fuerit per components. Acta II Congressus Internationalis «De Metabolomics bonorum aequationem esse meliori mutuae biotechnological». (Moscow, June 6-7, 2019, FGBNU VILAR). Moscow: VILAR. 2019. 615p. P.77-81. (russian) 